\title{
Higher Education in
}

\section{the United States: The Road Ahead}

Achievements of the federal administration in education during the Ninetyfifth Congress are summarized as well as plans for the Ninety-sixth Congress. Considering the future of higher education in the United States, the author looks at possible changes and what they may mean. Elements discussed are the composition of the student body and of the teaching faculty, use of campus facilities, financing of higher education, kinds of academic programs offered and their quality, and the role of the federal government.

I

AM DELIGHTED to join you here on the anniversary of your organization. I understand that the association celebrates a "big" birthday as you meet here in Boston this week. So congratulations on reaching your fortieth anniversary and best wishes for many more.

I am told that this is the first national conference for this particular body of the American Library Association, the Association of College and Research Libraries. I am happy to join you on what apparently has resulted in a very successful first voyage in this effort, too.

\section{The Present ReCoRD}

Though I have come here to speak on the future of higher education, let me take a few minutes to share with you some recent events that make these exciting times in our nation's capital, especially for those of us in education.

Since April 1977 those of us at the federal level have been bringing messages that were predictive in nature-telling our audiences what this administration intended to do in the field of education. Today I can come before you with enthusiasm and with much sense of accomplishment in the suc-

Mary F. Berry is assistant secretary for education, United States Department of Health, Education and Welfare, Washington, D.C. cesses which we achieved during the Ninety-fifth Congress.

Let me say at the outset that:

- If ever there was a champion of education;

- If ever there was the embodiment of a commitment to education;

- If ever there was a friend of education; That person is Jimmy Carter.

Having experienced a dearth of that kind of commitment in recent administrations, those of us in education are beginning to be "born again" in the belief that education is rightfully gaining its due as a number one priority in this society.

President Carter requested-and gotthe largest single increase in education services in our nation's history. Education appropriations were signed in October.

The reauthorization of the Elementary and Secondary Education Act of 1965 comprised the most significant rewrite of that legislation since it was enacted.

The centerpiece of that legislation is on the development of basic skills-an indication of the president's heartfelt commitment to provide our country's children with the basic tools to function in this society.

This legislation:

1. Reaffirms and strengthens the commitment established thirteen years ago to programs which ensure access and equal educational opportunity to poor and educationally needy children; 
2. Ensures that all children in the nation's schools master basic skills of reading, writing, and arithmetic;

3. Creates a new federal, state, and local partnership to help carry out these priorities while reducing the paperwork burden.

Specifically, this legislation authorizes about fifty programs, including a dozen major new ones, and provides for spending of more than $\$ 55$ billion over the next five years. We hope this will mean more students entering higher education institutions who know how to read, write, and think and who will be able to use the library, that most important facility, from the start.

In higher education, we are proud of the Middle Income Student Assistance Act which was signed just this last week and which represents a landmark commitment to aiding families with children in colleges and universities.

This bill authorizes several significant changes in the student assistance programs. The changes will provide more generous grants to low-income students and make eligible students from families with incomes up to $\$ 25,000$. In fiscal year 1978 , about 2.1 million students from families with incomes up to $\$ 15,000$ were eligible for Basic Educational Opportunity Grants. An additional 1.2 million students from middle-income families will now be eligible. This marks the largest infusion of funds for middle-income students since the 1944 GI Bill.

The bill also expands the Guaranteed Student Loan Program so that any student who has the need will be eligible for federally guaranteed and heavily subsidized loans of up to $\$ 2,500$ a year. No interest will be charged on those loans while the student is in college.

This particular legislation, passed in the final hours of Congress, was the president's alternative to various tuition tax credit proposals which failed in the Ninety-fifth Congress.

Ultimately, we came through the Ninety-fifth Congress with the largest education budget in history- $\$ 12.4$ billion. Elementary and Secondary Education Act appropriations were well over the \$3-billion mark with an increase of over $\$ 358$ million in the previous year. Financial aid to students totaled nearly $\$ 4$ billion with an in- crease of over $\$ 668$ million. The total Education Division appropriations increased by over $\$ 1$ billion in the previous year.

While we were not successful in the passage of legislation which would establish a separate Department of Education, we are determined that we shall not fail in that goal come the Ninety-sixth Congress.

President Carter has reiterated his commitment to this goal in recent days. He will send that bill back to Congress in the coming session. The Senate, as you may recall, passed the bill, but the clock ran out on the House side, and the bill did not come to a vote. Vice-President Mondale has recently stated that President Carter will have a signing ceremony on this bill before the Ninety-sixth Congress adjourns. I plan to be there for that ceremony.

I believe this is an education record of which we can be proud, and we are hopeful that our proposals for the reauthorization of the postsecondary education programs will fare as well in the Ninety-sixth Congress.

\section{Higher EDUCATION AND LibRARIES}

If there is one fact about colleges and universities, it is that they have changed at a faster rate than ever before in the sixties and seventies.

Our student bodies are more diverse than ever before. Students who once would not have attended colleges are attending. Unfortunately, there is not much diversity in faculties and administrations. Enrollments have increased. Our curriculum has been influenced by our changing society, technology, and the needs which we perceive as a nation.

In recent decades, academic libraries have managed to maintain the changing pace necessary to provide the essential resources which these times demand. The key to that adaptability has been in their ability to discern trends of importance before they occur. But the challenges may be even greater for academic libraries today and in the future.

Reading skills of college students are not what they once were. Where yesterday's college student came to college predisposed to reading and libraries and took pleasure in them, today's college freshman is said to arrive on campus with an experience of 
15,000 hours of television viewing. One does not dare to speculate how much reading accompanied that student to the campus. We hope our new legislation will remedy this, but, for now and the next few years, you will see the disinterested reader in your institutions.

Today we are faced with extremely varied student bodies, with extremely diverse skills and needs. Demographic patterns will continue to alter the composition of the student body in the decades to come. Indeed, the challenge of the future may be in serving the same individual at different periods in his or her life.

But the test for all academic libraries will be in serving all of these students adequately. Libraries need to use new technologies that make reading seem as much fun as television viewing. They must find resources to fund technological improvements and book purchases. And they must be creative in finding ways to store and retrieve materials consistent with realistic space demands. They must persuade presidents, foundations, and legislators to increase their budgets.

Federal support for college library resources in fiscal year 1979 totals $\$ 9,975,000$ and $\$ 6,000,000$ for research libraries. And we are requesting an additional $\$ 2,000,000$ in supplemental funds for library demonstration projects. In the reauthorization, we will fully consider what, if any, changes need to be made in our efforts.

\section{LOOKING AHEAD}

What do we foresee in higher education? While predictions are guesswork at best in this fast-changing society of ours, we can point to some developing patterns that every institution must keep in mind when decisions are made about the future.

\section{The Students}

The profile of the traditional student will continue to change in the years ahead. The 1980 s will see a decrease in the numbers of traditional college-age youth (eighteen to twenty-four). An older population, those between twenty-five and thirty-one, will continue to rise at least until 1988.

While the traditional college-age group will decline in the next decade, that will not be the case for blacks, Hispanics, or Hispanic-blacks until a few years later, since these groups have younger populations.

During the early seventies, higher education experienced an increase of 145 percent in students who were over thirty. We found many traditional college-age students stopping after high school to take jobs, secure incomes, and pursue other endeavors before continuing their education.

We knew male students would enroll-as an alternative to the draft, at least during the Vietnam War. Now we have a lottery system and a change to an all-volunteer military. We also have a phaseout of the GI Bill.

The narrowing of the earnings gap between those with and those without college diplomas may have discouraged potential college-bound youth.

An older student population will need flexible postsecondary educational opportunities - at the undergraduate and graduate level and in experimental nondegree programs.

The combined forces of demography and attendance of traditional and nontraditional students are anticipated to have an overall stabilizing effect on enrollment.

What will be the impact of these factors?

1. Part-time education will become increasingly popular, particularly as institutions make strong efforts to attract those in the twenty-five- to forty-four-year-old age groups.

2. The rising trend in enrollment for graduate study is likely to continue but at a lesser rate than during the current and past decades.

3. The slackening of the high-pay job opportunities for college graduates, the narrowing gap between earnings of those with college diplomas and those without, the sluggishness in the wage increases of the college graduate are likely to continue if we do not solve our economic problems.

It is hard to determine the extent to which these perceptions of the future will affect the current college-going decisions of youth.

It could mean that college-age students will be more selective about education in anticipation of job and earning opportunities. It may be that the college gradu- 
ates not able to find suitable jobs will be inclined to continue their education. Maybe the new higher education standard will become graduate degrees. The impact on society, in general, may be that we have captives in school who shouldn't be there. Another approach could be to maintain current standards with a focus on quality and the scaling down of the academic enterprise. But, of course, we are experiencing a period of expansion.

\section{The Faculty}

We know that personnel costs account for more than one-half of budgets. Although salary opportunities have not increased, the percent of college and university faculty organized by unions in recent years has increased from less than 1 percent in 1967 to almost 12 percent by 1976 . There has been a rapid emergence of collective bargaining through unionization. Not unexpectedly, a high priority of faculty unions is to save and preserve the security of the experienced professors.

There was the rapid tenuring of the faculty. Between 1970 and 1976, the proportion of all full-time faculty that were either full or associate professors grew from $\mathbf{4 0}$ percent to about 47 percent. In 1977 the percent with tenure had grown to 56.4 percent.

A sharp decline in new faculty job openings and the strengthening of the tenure system have resulted in an older faculty, which likely will continue to age as fewer people leave and fewer are hired. Median age of full-time faculty was 38.5 in 1970 and 40.6 years in 1975. No new blood in the faculty can have a devastating effect on quality.

Since 1959, pay raises for professors and administrators has gone up about 6 percent annually, while pay for other workers has increased by 8 percent. The lag may be attributed to an adjustment after the rapid surge of the sixties. On the whole, however, there has been a worsening of faculty wages, and pressures to correct this are likely to increase in the future.

Also significant is the increase in parttime personnel. Between 1973 and 1977 , full-time faculty grew by 9 percent compared to 38 percent in part-time faculty.
The growth of part-time faculty in two-year schools is even more dramatic at 80 percent. For many institutions, hiring of parttime faculty circumvents costly fringe benefits, provision of office space, and making hiring commitments leading to tenure decisions. What effect will this have on parttime personnel? The effects could be positive if there were job sharing and tenure, but there might be a negative impact on productivity. We must watch this development very carefully.

It is premature to speculate on the impact of no new faculty on quality educational services or the rise in the numbers of parttime teachers on the learning environment of institutions.

\section{The Campus}

What happens to the campus physically will be determined by the growth or decrease in student populations.

Plant utilization and growth will be put to the test not only by financial constraints which have always accompanied higher education, but by new constituencies such as the handicapped which we are legally obligated to serve.

Facilities sharing may become an attractive option. Some of this already is occurring in consortia-like arrangements.

\section{Finances}

A number of factors have begun to adversely affect revenues of institutions. They include depressed wages, higher tuitions, cutting operating costs, and deferring maintenance and investment in plant and equipment. Though these actions are necessary to meet current financial situations, we do not believe that they are a permanent solution to budget problems.

Further, most private institutions have had to devote a larger share of their revenues to student aid, partly to offset the low-tuition advantage of public institutions. But relief to this situation will be provided by the Middle Income Student Assistance Act.

Additionally, endowment income to finance private educational expenditures has steadily declined, and there is no prospect for a reversal of this trend.

Other serious threats to private liberal 
arts colleges and to liberal arts programs in all institutions are the reduction in the attractiveness of the liberal arts education and the perception, of students and sponsors alike, that the weight placed on a liberal education may not be warranted.

In 1970 one in six of all students enrolled in postsecondary schools for the first time selected a vocational program that did not lead to a degree. The ratio went up to one in four in 1975. Choice of vocational subjects is prevalent in two-year colleges.

These factors raise legitimate questions about the appropriate source of funding for the continued existence of some of our postsecondary institutions. Who should pay to keep them going?

\section{Program Offerings and Quality}

In the face of financial difficulties and stable or even declining enrollments, institutions have continued to increase the number and diversity of the programs which they offer, in part, to stem the tide of declining enrollments.

The response has not necessarily been to the potential demand from new clients. In many cases we can see that old wine is being offered in new bottles under different and more attractive labels.

Judgments on the quality of students, institutions, and programs are difficult to determine and may not be appropriate for us as federal officials. But there is a general presumption that standards of college education have been eroding. There is general agreement that entry standards are declining as measured by the long-term decline in SAT scores.

Current attempts are being made to assess the quality of institutions and their programs in a number of states.

In the future we are likely to witness a growing interest and movement within higher education institutions toward minimal standards for college education and stricter justification for offerings in terms of size and quality.

A related development is the renewed interest in "core" curriculum or a reinstitution of general education requirements. The proliferation of courses of little or no academic value and the enormity of course choices allowing a student to opt for less structure and diluted content have prompted debate on alternative means of tackling the problem. Some institutions have already put a back-to-the-basics or an almost-backto-the-basics emphasis into effect.

One set of proposals involves prescribing that students take an agreed group of courses before graduation. A second alternative goes a step further by attempting to define a set of testable knowledge skills as a requirement for graduation.

\section{THE Federal Role in the Future}

The overriding premise of federal support in the past has been that qualified students should have an opportunity to attend postsecondary education and that the responsibility for financing education should be shared among parents, students, the private sector, and various levels of government. That premise has resulted in the development of a commitment to:

- Reducing financial barriers to postsecondary education through entitlements for students in need of financial assistance. Passage of the Middle Income Student Assistance Act is the most recent example of this continued commitment.

- Enhancing the capacity of students to finance their own education through loans and incentives for part-time employment opportunities.

- Assisting in meeting the needs of specially disadvantaged groups such as minorities, women, and the handicapped.

- Providing selective support for improving the physical, financial, and intellectual capacity of postsecondary institutions, in particular those that serve special purposes.

- Finally, there has been a commitment to stimulate the supply of some specialized skill areas and research in selected fields that are of national interest.

During the reauthorization of the higher education legislation we need to reexamine our role in education.

- We need to reconsider the premises and the commitments to which the federal government has adhered in the past.

- There are some who would argue that the current patterns of financing higher education are totally irrational from an economic standpoint.

- There are arguments that there is a 
surplus of college graduates and that any future student subsidy will merely contribute to the unemployment rolls of college graduates.

- Do we continue to provide financial stress aid to developing institutions, and how?

- Should the needs for changes in physical facilities in higher education required by law be met through federal assistance? How much aid should we provide to institutions?

All of these issues will challenge the federal role in the immediate future.

As one observer put it: "The next decade will try the souls of those connected with colleges and universities. Enrollments are projected to go down. Funds for instruction will grow more slowly than in any period since World War II. The 1980s may well become the Dark Ages of higher education as college graduates will find it increasingly difficult to land jobs which utilize the training they received."

The decades ahead will, of course, be trying times for policy analysts, for planners, for educational providers, for administrators, for those who work in higher education, and for the society they will shape. Going into that time frame with a budget-cutting mentality will make it no easier. The point is that innovation and adaptability will be necessary in meeting the challenges of the future.

At the federal level a sensitivity, concern, and commitment to education, as that more recently illustrated by the Carter administration, will serve as a positive environment in which to seek the solutions. No less important will be the role of those in higher education to define, shape, and help us determine that policy which will ultimately affect us all. 